\title{
Pemanfaatan Rice Husk Ash Dan Bottom Ash Sebagai Bahan Campuran Pada Beton
}

\author{
Yusrianto ${ }^{* 1}$, Jonie Tanijaya *2, Suryanti Rapang Tonapa *3 \\ *1 Mahasiswa Program Studi Teknik Sipil, Universitas Kristen Indonesia Paulus, Makassar \\ Email Yusriantoukip@gmail.com \\ *2 Dosen Program Studi Teknik Sipil, Universitas Kristen Indonesia Paulus, Makassar \\ Email Jonie.tanijaya@gmail.com \\ *3 Dosen Program Studi Teknik Sipil, Universitas Kristen Indonesia Paulus, Makassar \\ Email Suryantirt19@gmail.com
}

\begin{abstract}
ABSTRAK
Penelitian ini menggunakan material dari limbah Rice Husk Ash (RHA) sebagai bahan susbtitusi semen dan Bottom Ash (BA) sebagai substitusi agregat halus pada campuran beton. Metodologi dalam penelitian ini melakukan pengujian karakteristik material dan pengujian sifat mekanik beton menggunakan variasi $\mathrm{RHA} 0 \%, 10 \%, 15 \%$ serta variasi $\mathrm{BA} 30 \%$ dengan kuat tekan rencana $25 \mathrm{MPa}$ metode $\mathrm{ACl}$ 211.2-98 pada umur pengujian 7, 21, dan 28 hari. Hasil penelitian menggunakan bahan substitusi RHA dan BA pada umur 28 hari diperoleh nilai kuat tekan rata-rata berturut-turut yaitu 26,125 MPa, 25,559 MPa, dan 25,276 MPa. Kuat tarik belah rata-rata berturut-turut diperoleh 2,451 MPa, 2,145 MPa, dan 1.909 MPa. Kuat lentur rata-rata berturut-turut adalah 3,878 MPa, 2,921 MPa, dan 2,871 MPa. Modulus elastisitas ratarata berturut-turut 17939,480 MPa, 11532,278 MPa, 9227,208 MPa. Penggunaan RHA dan BA sebagai bahan substitusi dapat mempengaruhi sifat mekanik beton berdasarkan besarnya variasi, semakin besar variasi yang digunakan sifat mekanik beton semakin menurun.
\end{abstract}

Kata Kunci : rice husk ash, bottom ash, sifat mekanik beton

\begin{abstract}
The purpose of this study was to determine the aggregate characteristics and concrete strength of the Battang River material. This type of research uses the American Concrete Institute method with the identification of cylindrical specimens with a diameter of $15 \mathrm{~cm}$ and a height of $30 \mathrm{~cm}$, a beam with a length of $60 \mathrm{~cm}$, width of $15 \mathrm{~cm}$, thickness of $15 \mathrm{~cm}$. The results of the research on the plan compressive strength test $23 \mathrm{Mpa}$, amounting to $23.861 \mathrm{Mpa}$, the compressive strength plan $30 \mathrm{Mpa}$, amounting to $31.501 \mathrm{Mpa}$, the split tensile strength test with the compressive strength plan $23 \mathrm{Mpa}$ is 1.957 $\mathrm{Mpa}$ and the compressive strength plan $30 \mathrm{MPa}$ is $2.769 \mathrm{Mpa}$, the strength test flexural compressive strength plan $23 \mathrm{Mpa}$ is $3.022 \mathrm{Mpa}$, for compressive strength plan $30 \mathrm{Mpa}$ is $3.425 \mathrm{Mpa}$. The aggregate characteristics of the Battang river meet the Indonesian National Standard and can achieve the planned compressive strength value.
\end{abstract}

Keywords: rice husk ash, bottom ash, compressive strength

\section{PENDAHULUAN}

Indonesia dikenal sebagai salah satu negara penghasil beras terbanyak di Dunia. Beras merupakan hasil penggilingan dari gabah yang digiling untuk memisahkan kulit gabah dengan butiran beras. Kulit gabah tersebut merupakan limbah organik yang sering disebut dengan sekam padi yang selama ini hanya digunakan sebagai bahan bakar untuk pembakaran batu merah, pupuk organik, dan bahkan biasanya hanya dibakar begitu saja dan tidak dipergunakan lagi. Sisa-sisa dari pembakaran sekam padi tersebut sering disebut dengan abu sekam padi (Rice Husk Ash). Jumlah limbah abu sekam padi saat ini semakin meninggkat, namun pengelolaannya belum digunakan secara optimal. Oleh karena itu perlu dilakukan pengelolaan, seperti pada bidang konstruksi yaitu dengan memanfaatkan abu sekam padi sebagai bahan substitusi pada campuran beton.

Bottom ash merupakan salah satu hasil dari limbah batubara yang digunakan sebagai sumber energi industri-industri di dunia terutama di Indonesia. Bottom ash pada umumnya memiliki ukuran butiran seperti agregat halus yang lolos saringan no $4(4,57)$. Jumlah limbah bottom ash yang semakin meninggkat tanpa adanya pengelolaan ataupun daur ulang yang berkelanjutan, tidak menutup kemungkinan lingkungan sekitarnya akan mudah terkena polusi akibat limbah tersebut. Namum dengan pemanfaatan bottom ash sebagai bahan pengganti agregat halus, dapat mengurangi pencemaran lingkungan akibat penumpukan limbah bottom ash sisa pembakaran batubara. 
Paulus Civil Engineering Journal

E- Jurnal Teknik Sipil UKI-Paulus Makassar http://ojs.ukipaulus.ac.id/index.php/pcej

Berdasarkan penelitian sebelumnya oleh Pris Hendri Lumban Tobing menggunakan abu sekam padi dan fly ash sebagai pen-substitusi semen. Pada penelitian ini menggunakan variasi abu sekam padi $0 \%, 5 \%, 10 \%$, dan $13 \%$ dan fly ash $0 \%, 10 \%, 15 \%$ dan $18 \%$ dengan kuat tekan rencana $25 \mathrm{MPa}$ yang diuji pada umur 7, 14 dan 28 hari. Nilai kuat tekan pada beton normal ASPF 28.4 MPa, dengan variasi fly ash pada benda uji ASPF1 28.8 MPa, ASPF2 25.2 $\mathrm{MPa}$, dan ASPF3 memiliki kuat tekan terendah yakni 22.9 MPa.[1] Sedangkan pada penelitian Surya Pradita yaitu memanfaatkan abu dasar (bottom ash) sebagai bahan substitusi pasir pada beton mutu normal. Pada penelitian ini menggunakan komposisi optimal penggantian limbah abu dasar dapat digunakan dalam beton kualitas normal (K-100, K175 dan K-250) dan persentase abu dasar (bottom ash) yang digunakan $0 \%, 10 \%, 20 \%$, dan $30 \%$. Hasil penelitian didapatkan kuat tekan tertinggi pada variasi Bottom Ash 30\% sebesar 31,361 MPa. [2]. Kadar variasi $5 \%$ abu sekam padi pada beton baik untuk pengujian self compacting concrete [3], kapur bebas yang merupakan hasil reaksi dari hidrasi semen dengan air menghasilkan senyawa padat yang meningkatkan kuat tekan beton [4], beton normal tidak menggunakan alkali activator dalam proses pembuatannya [5]

Dalam penelitian ini dilakukan aplikasi Rice Husk Ash (RHA) sebagai substitusi semen dan Bottom Ash (BA) sebagai substitusi agregat halus dengan menggunakan variasi abu sekam padi $0 \%, 10 \%, 15 \%$ dan bottom ash $30 \%$ pada tiap-tiap variasi campuaran. Untuk menentukan sifat mekanik beton seperti kuat tekan, tarik belah, kuat lentur dan modulus elastisitas beton dengan menggunakan mutu beton rencana yaitu f'c $25 \mathrm{MPa}$ pada variasi pengujian umur 7 hari, 21 hari dan 28 hari.

\section{Kuat Tekan Beton (SNI 1974-2011)}

Kuat tekan merupakan besarnya beban persatuan luas, sehingga mengakibatkan silinder beton hancur karena beban yang dihasilkan oleh alat uji tekan. [3] Berikut merupakan persamaan kuat tekan beton (1):

$$
f^{\prime}{ }_{c}=\frac{\mathrm{P}}{\mathrm{A}}
$$

Keterangan :

$f_{C}^{\prime}=$ Kuat tekan $(\mathrm{MPa})$

$\mathrm{P}=$ Beban maksimum $(\mathrm{N})$

$A=$ Luas penampang benda uji $\left(\mathrm{mm}^{2}\right)$

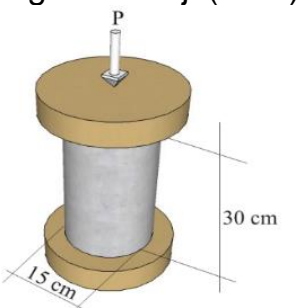

Gambar 1. Uji kuat tekan
Volume 2 No.4, Desember 2020

ISSN Online : $x x x x-x x x x$
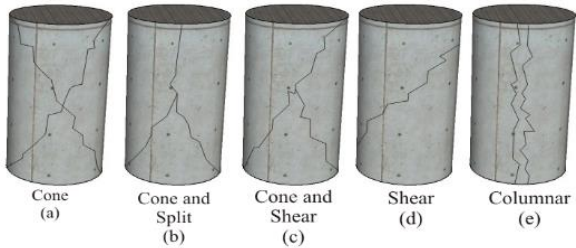

Gambar 2. Jenis - jenis retakan pada beton

(SNI 1974-2011)

\section{Kuat Tarik Belah Beton (SNI 2491-2014)}

Kuat tarik belah merupakan kuat tarik belah dari silinder beton yang diberikan beban pada sisi panjangnya. Nilai kekuatan tarik belah pada beton pada umumnya rendah dan kuat tekan beton tidak berbanding lurus dengan kuat tarik belah beton. [6]

$$
f_{t}=\frac{2 \mathrm{P}}{\pi \mathrm{LD}}
$$

Keterangan :

$f_{t} \quad=$ Kuat tarik belah (MPa)

$\mathrm{P}=$ Beban Maksimum (N)

$\mathrm{L} \quad=$ Panjang silinder beton $(\mathrm{mm})$

D $\quad=$ Diameter silinder beton $(\mathrm{mm})$
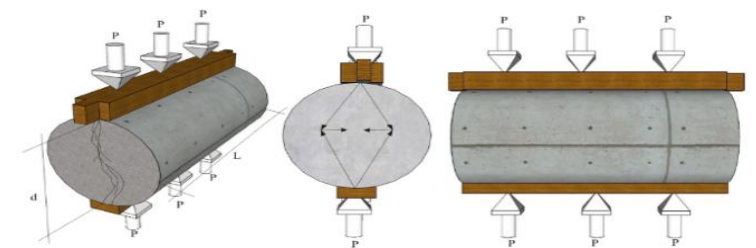

Gambar 3. Uji tarik belah

\section{Kuat Lentur Beton (SNI 4431-2011)}

Kuat lentur merupakan kemampuan dari benda uji balok untuk menahan gaya yang tegak lurus pada pada permukaan benda uji sehingga mengakibatkan balok beton tersebut patah. [5]

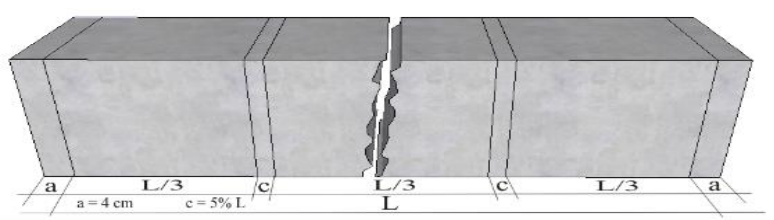

Gambar 4. Kuat lentur dengan keruntuhan pada tengah bentang balok

$\mathrm{f}_{\mathrm{r}}=\frac{\mathrm{PxL}}{\mathrm{bxh}^{2}}$

Pada persamaan (3) digunakan apabila terjadi keruntuhan di tengah bentang balok dan untuk keruntuhan yang terjadi pada bagian luar tengah bentang (Gambar 5) digunakan Persamaan (4).

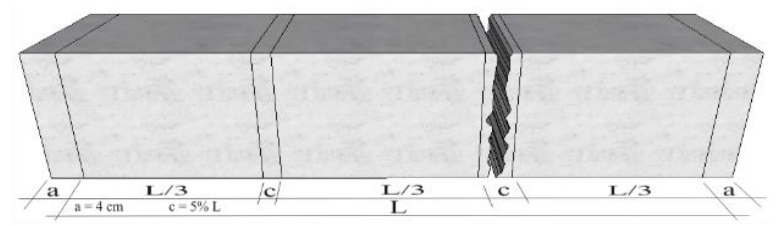

Gambar 5. Kuat lentur dengan keruntuhan pada $>5 \%$ dari bentang balok 


$$
f_{r}=\frac{\mathrm{Pxa}}{\mathrm{bx} \mathrm{h}^{2}}
$$

Sedangkan untuk benda uji dengan keruntuhan di luar tengah bentang balok dan di luar batas $5 \%$ dari bentang balok maka hasil dari pengujian tersebut tidak akan digunakan, seperti pada gambar di bawah ini.

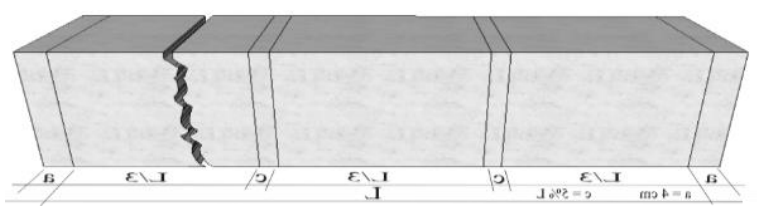

Gambar 6.Pengujian kuat lentur dengan keruntuhan di luar tengah bentang balok

Keterangan:

$t_{r}=$ Kuat lentur (MPa)

$P=$ Beban Maksimum (N)

$\mathrm{L}=$ Jarak bentang dengan garis perletakan $(\mathrm{cm})$

$\mathrm{h}=$ Lebar penampang arah vertikal $(\mathrm{cm})$

b = Lebar penampang arah horizontal $(\mathrm{cm})$

$a=$ Jarak rata-rata penampang patah dari tumpuan luar terdekat yang diukur pada 4 tempat pada sudut dari bentang balok $(\mathrm{cm})$.

\section{Modulus Elastisitas Beton (ASTM C 469 - 02)}

Modulus elastisitas beton adalah perbandingan dari tekanan yang diberikan dengan perubahan bentuk persatuan panjang. [7] Modulus elastisitas ditentukan dari perubahan tegangan terhadap regangan dalam batas elastisnya. [8]

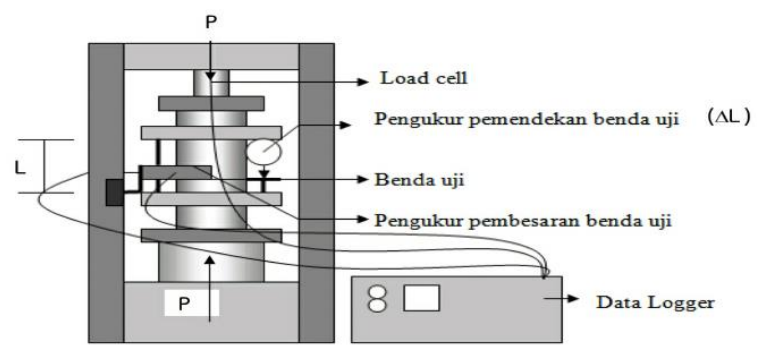

Gambar 7. Alat pengujian modulus elastisitas beton

$E_{c}=\frac{\mathrm{S} 2-\mathrm{S} 1}{\varepsilon_{1}-0,00005}$

Keterangan:

$E_{c}=$ Modulus elastisitas (MPa)

$S_{2}=$ Besar tegangan saat $40 \%$ beban batas (MPa)

$S 1=$ Besar tegangan saat regangan 0,00005 (MPa)

$\varepsilon_{1}=$ Regangan longitudinal saat $40 \%$ beban batas

\section{METODE}

1. Pengadaan Material

a. Semen yang digunakan adalah Portland Composite Cement (PCC) produksi PT Semen Tonasa. b. Agregat halus yang digunakan adalah abu batu dan agregat kasar berupa batu pecah yang diperoleh dari Sungai Jeneberang, Sulawesi Selatan.

c. Air sumur bor di Laboratorium Teknologi dan Bahan Beton Universitas Kristen Indonesia Paulus, Makassar.

d. Abu Sekam Padi (Rice Husk Ash)

e. Bottom Ash

2. Persiapan Alat Penelitian

a. Timbangan

b. Oven

c. Saringan/Ayakan

d. Mesin penggetar ayakan (shieve shaker)

e. Kerucut Terpancung (Cone)

f. Mesin Pencampur Bahan (mixer/molen)

g. Cetak Silinder $30 \times 15$

h. Cetak Balok $60 \times 15 \times 15$

i. Bak Perendaman

j. Kerucut Abrams

k. Mesin Pengujian

I. Alat-alat Pendukung lainnya

3. Pemeriksaan Karakteristik Material

a. Agregat Halus

Tabel 1. Pedoman karakteristik agregat halus Karakteristik

Pedoman

\begin{tabular}{ll}
\hline Kadar lumpur (\%) & SNI 03 - 4142-1996 \\
Kadar organik (warna) & SNI 2816-2014 \\
Kadar air (\%) & SNI 03- 1971- 2011 \\
$\begin{array}{l}\text { Berat volume padat } \\
\left(\mathrm{kg} / \mathrm{m}^{3}\right)\end{array}$ & SNI 03 - 4804- 1998 \\
$\begin{array}{l}\text { Berat volume gembur } \\
\left(\mathrm{kg} / \mathrm{m}^{3}\right)\end{array}$ & SNI 03 - 4804-1998 \\
Absorpsi (\%) & SNI 1970 - 2008 \\
SSD & SNI 1970 - 2008 \\
Analisa Saringan & SNI ASTM C136:2012 \\
\hline
\end{tabular}

Tabel 2. Karakteristik agregat halus

\begin{tabular}{lcc}
\hline Karakteristik agregat & Hasil & Interval \\
\hline Kadar Air (\%) & 3,519 & $2,00-5,00$ \\
Zat Organik & No.2 & $<$ No.3 \\
Kadar Lumpur (\%) & 2,300 & $0,20-6,00$ \\
SSD & 2,265 & $1,60-3,20$ \\
Absorpsi (\%) & 1,523 & $0,20-2,00$ \\
Berat Volume Padat & & $1400-1900$ \\
(kg/m $\left.^{3}\right)$ & 1471,667 & \\
Berat Volume & 1413,333 & $1400-1900$ \\
Gembur $\left(\mathrm{kg} / \mathrm{m}^{3}\right)$ & 2,489 & $2,20-3,10$ \\
Modulus Kehalusan &
\end{tabular}

b. Agregat Kasar 
Paulus Civil Engineering Journal

E- Jurnal Teknik Sipil UKI-Paulus Makassar http://ojs.ukipaulus.ac.id/index.php/pcej

Tabel 3. Pedoman karakteristik agregat kasar

\begin{tabular}{ll}
\multicolumn{1}{c}{ Karakteristik } & \multicolumn{1}{c}{ Pedoman } \\
\hline Kadar lumpur, \% & SNI 03 - 4142-1996 \\
Kadar air, \% & SNI 03 - 1971- 2011 \\
$\begin{array}{l}\text { Berat volume padat, } \\
\left(\mathrm{kg} / \mathrm{m}^{3}\right)\end{array}$ & SNI 03 - 4804-1998 \\
$\begin{array}{l}\text { Berat volume gembur, } \\
\left(\mathrm{kg} / \mathrm{m}^{3}\right)\end{array}$ & SNI 03 - 4804-1998 \\
Absorpsi (\%) & SNI 1969-2008 \\
SSD & SNI 1969- 2008 \\
Analisa Saringan & SNI ASTM C136:2012 \\
\hline
\end{tabular}

\section{c. Bottom Ash}

Tabel 4. Hasil pengujian bottom ash

\begin{tabular}{lcc}
\hline \multicolumn{1}{c}{ Karakteristik } & Hasil & Interval \\
\hline Kadar Air (\%) & 3,519 & $3,00-5,00$ \\
Zat Organik & No.2 & $<$ No.3 \\
Kadar Lumpur (\%) & 2,300 & $0,20-6,00$ \\
Berat Jenis SSD & 2,265 & $1,60-3,20$ \\
$\begin{array}{l}\text { Absorpsi/Penyerapan } \\
(\%)\end{array}$ & 1,523 & $0,20-2,00$ \\
$\begin{array}{l}\text { Berat Volume Padat } \\
\left(\mathrm{kg} / \mathrm{m}^{3}\right)\end{array}$ & 1471,667 & $1400-1900$ \\
Berat Volume & 1413,333 & $1400-1900$ \\
Gembur $\left(\mathrm{kg} / \mathrm{m}^{3}\right)$ & 2,489 & $2,20-3,10$ \\
Modulus Kehalusan & & \\
\hline
\end{tabular}

d. Filler

Tabel 5. Karakteristik semen dan RHA

\begin{tabular}{clcc}
\hline No & Karakteristik Material & Hasil & Interval \\
\hline 1 & Berat Jenis PCC & 3,15 & $3,0-3,2$ \\
2 & Berat Jenis RHA & 3,005 & $3,0-3,2$ \\
\hline
\end{tabular}

\section{Mix Design (ACI 211.2-98)}

Tabel 6. Komposisi material dalam campuran beton per $1 \mathrm{~m}^{3}$ dalam satuan berat $(\mathrm{kg})$

\begin{tabular}{ccccccc}
$\begin{array}{c}\% \\
\text { RHA }\end{array}$ & PCC Air & $\begin{array}{c}\text { Agregat } \\
\text { Kasar }\end{array}$ & $\begin{array}{c}\text { Agregat } \\
\text { Halus }\end{array}$ & $\begin{array}{c}B A \\
(30 \%)\end{array}$ & $R H A$ \\
\hline $0 \%$ & 316,39 & 193 & 1129,877 & 488,95 & 209,55 & 0 \\
$10 \%$ & 284,75 & 193 & 1129,877 & 488,95 & 209,55 & 31,64 \\
$15 \%$ & 268,93 & 193 & 1129,877 & 488,95 & 209,55 & 47,46 \\
\hline
\end{tabular}

\section{Trial Mix}

Pembuatan trial mix dilakukan untuk mengetahui apakah komposisi yang telah dihitung memenuhi kuat tekan rencana $\left(f^{\prime} c\right)$. Dari hasil pengujian kuat tekan beton sampel trial mix menggunakan variasi abu sekam padi $0 \%$ dan $30 \%$ bottom ash umur 3 dan

Volume 2 No.4, Desember 2020

ISSN Online : $x x x x-x x x x$

7 hari diperoleh nilai kuat tekan diatas kuat tekan rencana yaitu $25 \mathrm{MPa}$. Jadi komposisi material untuk beton yang direncanakan tercapai.

\section{Pembuatan Benda Uji}

Cara pembuatan benda uji sesuai dengan aturan SNI 2493:2011 yaitu ;

\section{Pencampuran Bahan}

Pencampuran material bahan campuran sesuai dengan komposisi mix design dan ukuran yang sedemikian rupa sehingga menyisakan $10 \%$ kelebihan setelah pencetakan benda uji.

Pengujian slump test dengan slump test recana yaitu 75-100 mm.

(a)

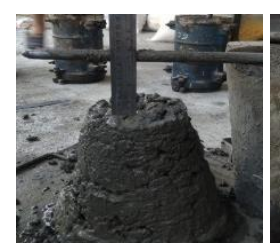

(b)

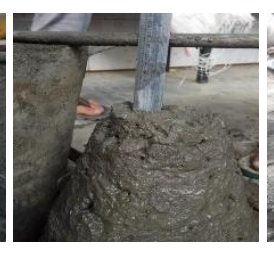

Gambar 8. Slump Test (c)

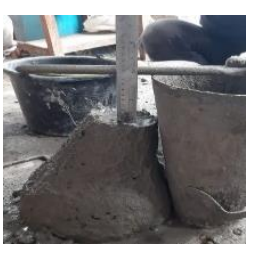

(a) RHA $0 \%+$ BA $30 \%$ yaitu $8 \mathrm{~cm}$,

(b) $\mathrm{RHA} 10 \%+\mathrm{BA} 30 \%$ yaitu $8,5 \mathrm{~cm}$

(c) $\mathrm{RHA} 15 \%+\mathrm{BA} 30 \%$ yaitu $9,5 \mathrm{~cm}$.

Pencetakan benda uji

Mencetak benda uji dilakukan berdekatan dengan tempat untuk penyimpanan selama 24 jam. Cetakan silinder diletakkan pada permukaan yang rata dan terhindar dari getaran ataupun gangguan lainnya.

Identifikasi benda uji atau pemberian kode identifikasi benda uji.

\section{Perawatan Benda Uji}

Benda uji yang telah dilepas dari cetakan dan diberikan kode dirawat dengan cara perendaman batas waktu pengujian kekuatan beton. Tujuan melakukan perawatan beton yaitu:

a. Mencegah terjadinya keretak pada permukaan benda uji yang diakibat oleh penguapan air yang terlalu cepat pada beton yang masih baru.

b. Menstabilkan hidrasi semen agar beton dapat mencapai kuat tekan yang telah direncanakan.

c. Pengujian Sifat Mekanik Beton

d. Pengujian Kuat Tekan

Pengujian kuat tekan beton akan dilakukan setelah melalui proses perawatan pada umur 7 hari, 21 hari, dan 28 hari yang dilakukan sesuai dengan SNI 1974 $-2011$. 
Paulus Civil Engineering Journal

E- Jurnal Teknik Sipil UKI-Paulus Makassar

http://ojs.ukipaulus.ac.id/index.php/pcej

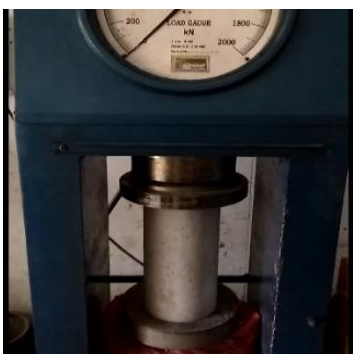

Gambar 9. Compression Testing Machine kapasitas $2000 \mathrm{KN}$

Pengujian Kuat Tarik Belah

Pengujian kuat tarik belah beton akan dilakukan dengan cara memberikan pembebanan pada sisi panjang silinder beton yang diuji pada umur 28 hari dilakukan sesuai dengan standar SNI 2491 - 2014.

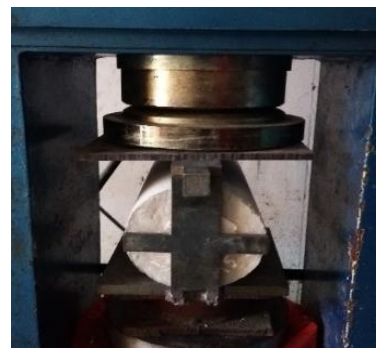

Gambar 10. Pengujian Kuat tarik belah beton

Pengujian Kuat Lentur

Pengujian kuat lentur pada beton dilakukan terhadap benda uji yang berbentuk balok dengan umur 28 hari sesuai dangan standar SNI 4431- 2011. Alat penguji kuat lentur yaitu Hydroulic Concrete Beam Testing Machine Kapasitas 20 Ton.

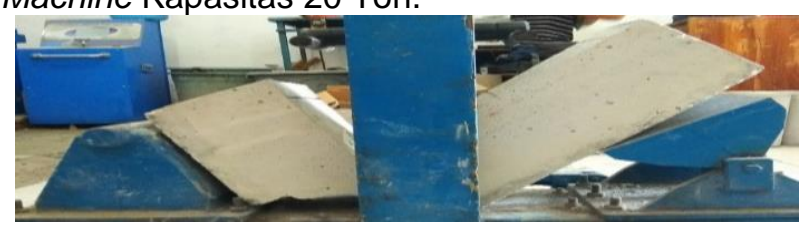

Gambar 11. Pengujian kuat lentur beton

Pengujian Modulus Elastisitas

Pengujian modulus elastisitas beton akan dilakukan setelah melalui proses perawatan pada umur 28 hari yang diuji bersamaan dengan pengujian kuat tekat sesuai dengan standar ASTM C 469 - 02. Alat yang digunakan yaitu alat penekan (Compression Testing Machine) kapasitas $2000 \mathrm{KN}$ dan Modulus Of Elasticity In Concrete Test Set.

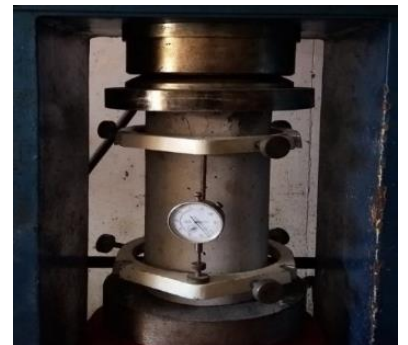

Gambar 12. Pengujian modulus elastisitas

\section{HASIL DAN PEMBAHASAN}

\section{Kuat Tekan Beton}

Tabel 8. Hasil pengujian kuat tekan beton $\mathrm{RHA} 0 \%+$ BA $30 \%$

\begin{tabular}{|c|c|c|c|c|}
\hline $\begin{array}{l}\mathrm{U} \\
\mathrm{m} \\
\mathrm{u} \\
\mathrm{r}\end{array}$ & $\begin{array}{c}\text { Kode } \\
\text { Benda Uji }\end{array}$ & $\begin{array}{l}\text { Kuat } \\
\text { Tekan } \\
\text { Aktual } \\
\text { (MPa) }\end{array}$ & $\begin{array}{c}\text { Rata-rata } \\
\text { Kuat } \\
\text { Tekan } \\
\text { Aktual } \\
(\mathrm{MPa})\end{array}$ & $\begin{array}{l}\text { Kuat } \\
\text { Tekan } \\
\text { (MPa) }\end{array}$ \\
\hline \multirow{3}{*}{7} & YT A1 7 & 16,977 & \multirow{3}{*}{16,788} & \multirow{3}{*}{25,828} \\
\hline & YT A2 7 & 15,845 & & \\
\hline & YT A3 7 & 17,542 & & \\
\hline \multirow{3}{*}{21} & YT A1 21 & 23,767 & \multirow{3}{*}{24,710} & \multirow{3}{*}{26,011} \\
\hline & YT A2 21 & 24,899 & & \\
\hline & YT A3 21 & 25,465 & & \\
\hline \multirow{3}{*}{28} & YT A1 28 & 26,031 & \multirow{3}{*}{26,125} & \multirow{3}{*}{26,125} \\
\hline & YT A2 28 & 16,977 & & \\
\hline & YT A3 28 & 15,845 & & \\
\hline
\end{tabular}

Tabel 9. Hasil Pengujian Kuat Tekan Beton RHA $10 \%+\mathrm{BA} 30 \%$

\begin{tabular}{|c|c|c|c|c|}
\hline $\begin{array}{l}\mathrm{U} \\
\mathrm{m} \\
\mathrm{u} \\
\mathrm{r}\end{array}$ & $\begin{array}{c}\text { Kode } \\
\text { Benda Uji }\end{array}$ & $\begin{array}{l}\text { Kuat } \\
\text { Tekan } \\
\text { Aktual } \\
(\mathrm{MPa})\end{array}$ & $\begin{array}{c}\text { Rata-rata } \\
\text { Kuat } \\
\text { Tekan } \\
\text { Aktual } \\
\text { (MPa) }\end{array}$ & $\begin{array}{c}\text { Kuat } \\
\text { Tekan } \\
(\mathrm{MPa})\end{array}$ \\
\hline \multirow{3}{*}{7} & YT B1 7 & 16,694 & \multirow{3}{*}{16,505} & \multirow{3}{*}{25,392} \\
\hline & YT B2 7 & 15,845 & & \\
\hline & YT B3 7 & 16,977 & & \\
\hline \multirow{2}{*}{21} & YT B1 21 & 23,484 & \multirow{2}{*}{24,144} & \multirow{2}{*}{25,415} \\
\hline & YT B2 21 & 23,767 & & \\
\hline
\end{tabular}




\begin{tabular}{|c|c|c|c|c|}
\hline & YT B3 21 & 25,182 & & \\
\hline \multirow{3}{*}{28} & YT B1 28 & 25,182 & \multirow{3}{*}{25,559} & \multirow{3}{*}{25,559} \\
\hline & YT B2 28 & 16,694 & & \\
\hline & YT B3 28 & 15,845 & & \\
\hline \multicolumn{5}{|c|}{$\begin{array}{l}\text { Tabel 10. Hasil Pengujian Kuat Tekan Beton RHA } \\
\qquad 15 \%+\text { BA } 30 \%\end{array}$} \\
\hline $\begin{array}{l}\mathrm{m} \\
\mathrm{u} \\
\mathrm{r}\end{array}$ & $\begin{array}{c}\text { Kode } \\
\text { Benda Uji }\end{array}$ & $\begin{array}{l}\text { Kuat } \\
\text { Tekan } \\
\text { Aktual } \\
\text { (MPa) }\end{array}$ & $\begin{array}{c}\text { Rata-rata } \\
\text { Kuat } \\
\text { Tekan } \\
\text { Aktual } \\
\text { (MPa) }\end{array}$ & $\begin{array}{l}\text { Kuat } \\
\text { Tekan } \\
\text { (MPa) }\end{array}$ \\
\hline \multirow{3}{*}{7} & YT C1 7 & 15,562 & \multirow{3}{*}{16,316} & \multirow{3}{*}{25,102} \\
\hline & YT C2 7 & 16,411 & & \\
\hline & YT C3 7 & 16,977 & & \\
\hline \multirow{3}{*}{21} & YT C1 21 & 23,767 & \multirow{3}{*}{23,861} & \multirow{3}{*}{25,117} \\
\hline & YT C2 21 & 24,616 & & \\
\hline & YT C3 21 & 23,201 & & \\
\hline \multirow{3}{*}{28} & YT C1 28 & 25,465 & \multirow{3}{*}{25,276} & \multirow{3}{*}{25,276} \\
\hline & YT C2 28 & 15,562 & & \\
\hline & YT C3 28 & 16,411 & & \\
\hline
\end{tabular}

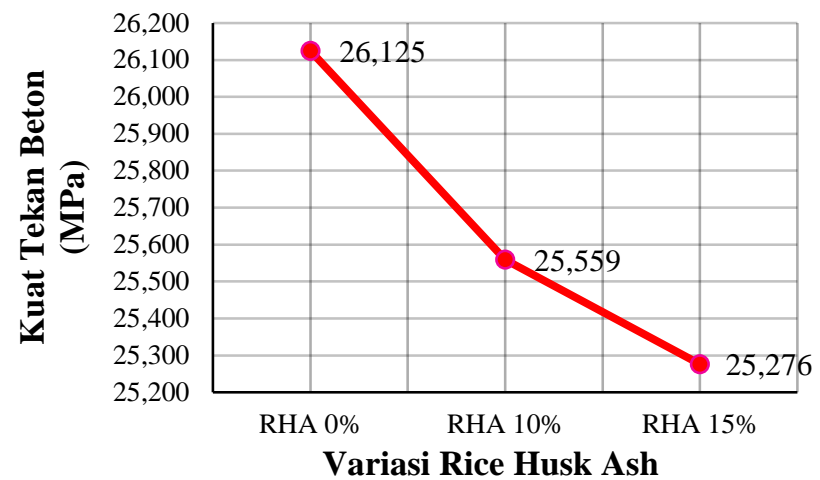

Gambar 14. Hubungan kuat tekan beton terhadap variasi $\mathrm{RHA}$

Hasil dari pengujian kuat tekan beton dengan kuat rencana ( $\mathrm{f}$ 'c) yaitu $25 \mathrm{MPa}$ pada variasi 'rice husk ash $0 \%, 10 \%, 15 \%$ sebagai substitusi semen dan variasi tetap boittom ash $30 \%$ sebagai substitusi agregat halus pada umur 28 hari yaitu berturut-turut sebesar $26,125 \mathrm{MPa}, 25,559 \mathrm{MPa}, 25,276 \mathrm{MPa}$ mengalami penurunan dari variasi RHA $0 \%$ ke RHA 10\% menurun sebesar $2,2 \%$, sedangkan variasi $\mathrm{RHA} 10 \%$ ke RHA 15\% mengalami penurunan sebesar 1,1\%.

2. Kuat Tarik Belah

Tabel 11. Hasil pengujian kuat tarik belah

\begin{tabular}{|c|c|c|c|c|}
\hline $\begin{array}{l}\text { Variasi } \\
\text { RHA }\end{array}$ & $\begin{array}{c}\text { Kode } \\
\text { Benda Uji }\end{array}$ & $\begin{array}{c}\text { Kuat } \\
\text { Tarik } \\
\text { Belah } \\
\text { Aktual } \\
\text { (MPa) }\end{array}$ & $\begin{array}{c}\text { Kuat } \\
\text { Tarik } \\
\text { Belah } \\
\text { Aktual } \\
\text { Rata- } \\
\text { rata } \\
(\mathrm{MPa}) \\
\end{array}$ & $\begin{array}{c}\text { Kuat } \\
\text { Tarik } \\
\text { Belah } \\
28 \text { Hari } \\
\text { Rata- } \\
\text { rata } \\
(\mathrm{MPa})\end{array}$ \\
\hline \multirow{3}{*}{$0 \%$} & YTB A 28 & 2,616 & \multirow{3}{*}{2,451} & \multirow{3}{*}{2,451} \\
\hline & YTB A 28 & 2,333 & & \\
\hline & YTB A 28 & 2,404 & & \\
\hline \multirow{3}{*}{$10 \%$} & YTB B 28 & 2,333 & \multirow{3}{*}{2,145} & \multirow{3}{*}{2,145} \\
\hline & YTB B 28 & 2,121 & & \\
\hline & YTB B 28 & 1,980 & & \\
\hline \multirow{3}{*}{$15 \%$} & YTB C 28 & 1,838 & \multirow{3}{*}{1,909} & \multirow{3}{*}{1,909} \\
\hline & YTB C 28 & 1,768 & & \\
\hline & YTB C 28 & 2,121 & & \\
\hline
\end{tabular}

Berdasarkan gambar 13 dapat dilihat bahwa kuat tekan yang diperoleh semakin meningkat seiring dengan besarnya umur pada beton, namun kuat tekan beton mengalami penurunan setiap bertambahnya variasi substitusi dari Rice Husk Ash.

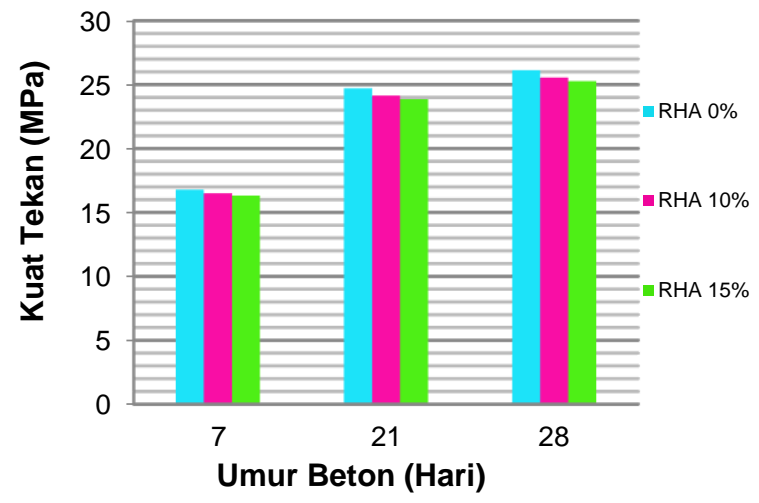

Gambar 13. Hubungan kuat tekan beton terhadap umur beton 


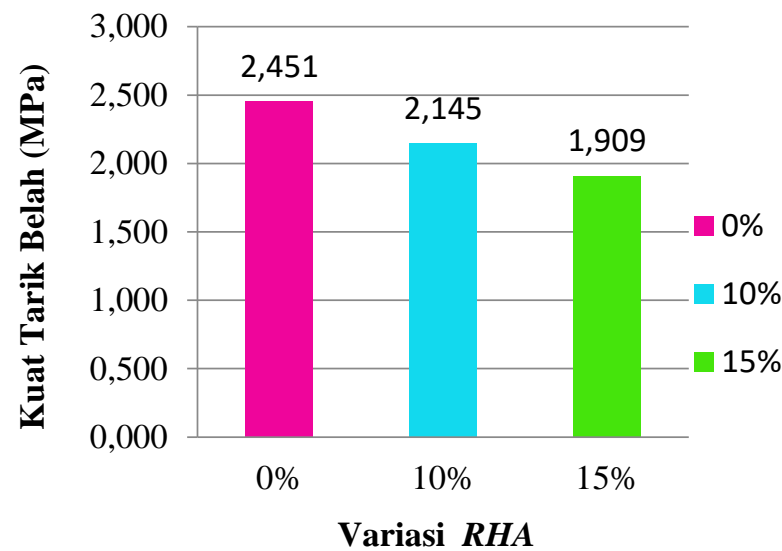

Gambar 15. Hubungan kuat tarik belah terhadap variasi $\mathrm{RHA}$

Berdasarkan gambar menunjukkan hubungan antara variasi $\mathrm{RHA}$ dengan kuat tarik belah, dimana nilai kuat tarik belah beton yang diperoleh mengalami penurunan setiap penambahan variasi rice husk ash pada campuran beton. Dari hasil pengujian didapatkan nilai kuat tarik belah tertinggi berada pada variasi substitusi RHA sebesar $0 \%$ sebesar 2,451 $\mathrm{MPa}$ dan nilai terendah berada pada variasi substitusi RHA sebesar $15 \%$ sebesar 1,909 MPa.

Hasil dari pengujian kuat tarik belah beton dengan kuat rencana ( $\left.f^{\prime} c\right)$ yaitu $25 \mathrm{MPa}$ pada variasi 'rice husk ash 0\%, 10\%, 15\% sebagai substitusi semen dan variasi tetap bottom ash 30\% sebagai substitusi agregat halus pada umur 28 hari yaitu berturut-turut sebesar 2,451 $\mathrm{MPa}, 2,145 \mathrm{MPa}$, dan 1,909 $\mathrm{MPa}$ mengalami penurunan dari variasi $\mathrm{RHA} 0 \%$ ke $\mathrm{RHA}$ $10 \%$ menurun sebesar $14,29 \%$, sedangkan variasi RHA $10 \%$ ke RHA $15 \%$ mengalami penurunan sebesar $12,35 \%$.

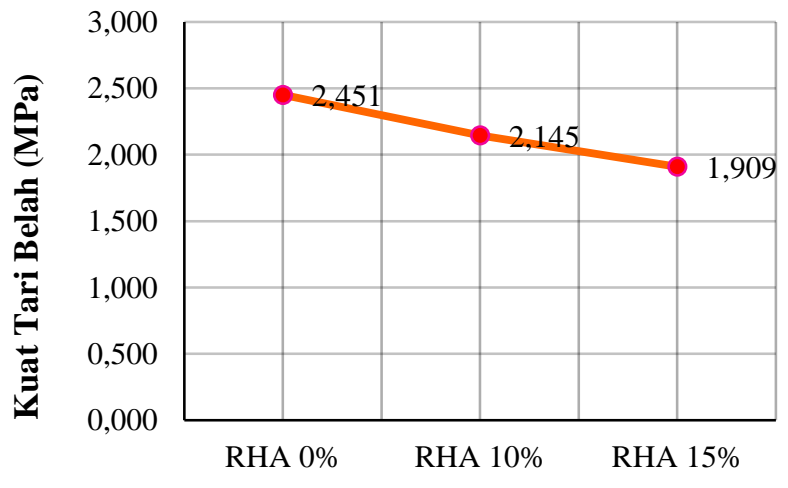

Variasi Rice Husk Ash

Gambar 16. Hubungan variasi substitusi RHA dan kuat tarik belah

3. Kuat Lentur Beton
Tabel 12. Hasil pengujian kuat lentur

\begin{tabular}{cccc}
\hline $\begin{array}{c}\text { RHA } \\
(\%)\end{array}$ & Kode & $\begin{array}{c}\text { Kuat } \\
\text { Lentur } \\
\text { Beton } \\
\text { (MPa) }\end{array}$ & $\begin{array}{c}\text { Rata-rata } \\
\text { Kuat Lentur } \\
\text { Beton } \\
\text { Aktual } \\
\text { (MPa) }\end{array}$ \\
\hline \multirow{2}{*}{0 YKL A 28 } & 3,928 & \\
& YKL A 28 & 3,626 & 3,878 \\
& YKL A 28 & 4,080 & \\
\hline & YKL B 28 & 2,720 & \\
$10 \%$ & YKL B 28 & 3,173 & 2,921 \\
& YKL B 28 & 2,871 & \\
\hline \multirow{3}{*}{$15 \%$} & YKL C 28 & 2,720 & \\
& YKL C 28 & 2,871 & 2,871 \\
\hline
\end{tabular}

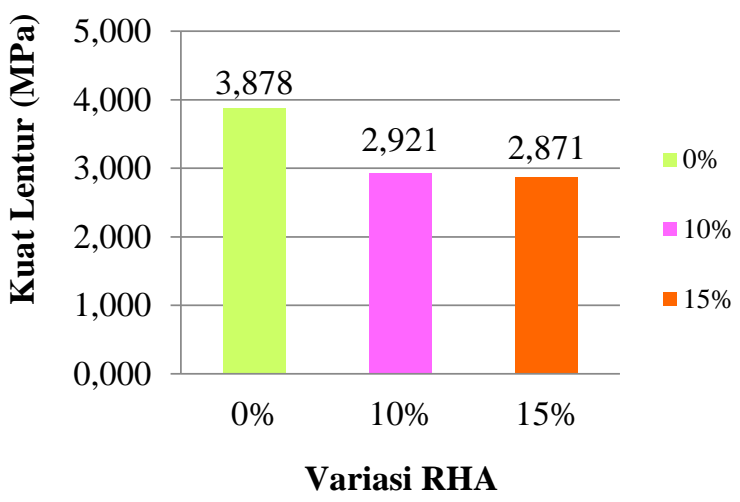

Gambar 17. Hubungan kuat lentur terhadap variasi $\mathrm{RHA}$

Berdasarkan gambar 17 menunjukkan hubungan antara kuat lentur dengan variasi $\mathrm{RHA}$, yaitu nilai kuat lentur beton mengalami penurunan setiap penambahan variasi rice husk ash pada campuran beton. Dari hasil pengujian didapatkan nilai kuat tarik belah tertinggi berada pada variasi substitusi RHA sebesar $0 \%$ sebesar 3,878 MPa dan nilai terendah berada pada variasi substitusi RHA sebesar $15 \%$ sebesar 2,871 MPa.

Hasil dari pengujian kuat lentur beton dengan kuat rencana (f'c) yaitu $25 \mathrm{MPa}$ pada variasi rice husk ash $0 \%, 10 \%, 15 \%$ sebagai substitusi semen dan variasi tetap boittom ash $30 \%$ sebagai substitusi agregat halus pada umur 28 hari yaitu berturut-turut sebesar 3,878 MPa, 2,921 MPa, dan 2,871 MPa mengalami penurunan dari variasi RHA $0 \%$ ke RHA 10\% menurun sebesar $32,76 \%$, sedangkan variasi $\mathrm{RHA}$ $10 \%$ ke RHA $15 \%$ mengalami penurunan sebesar $1,75 \%$. 
Paulus Civil Engineering Journal

E- Jurnal Teknik Sipil UKI-Paulus Makassar http://ojs.ukipaulus.ac.id/index.php/pcej
Volume 2 No.4, Desember 2020

ISSN Online : $x x x x-x x x x$

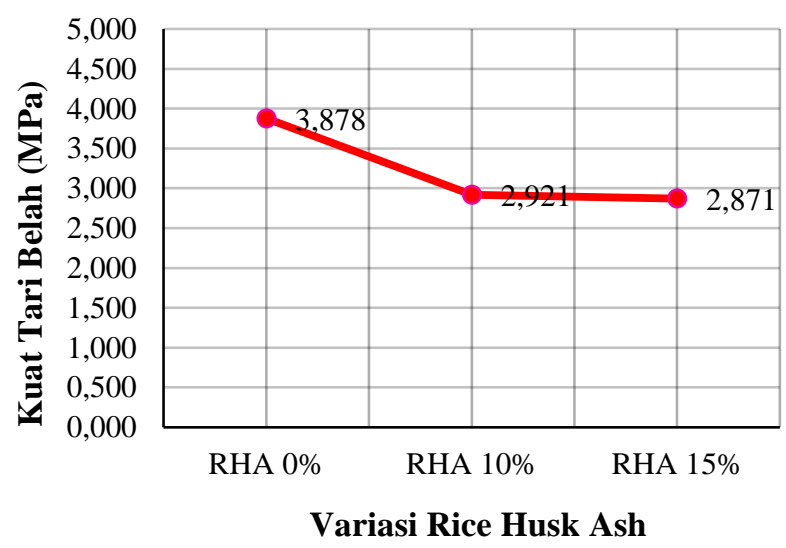

Gambar 18. Hubungan variasi substitusi RHA dan kuat lentur beton

Modulus Elastisitas Beton

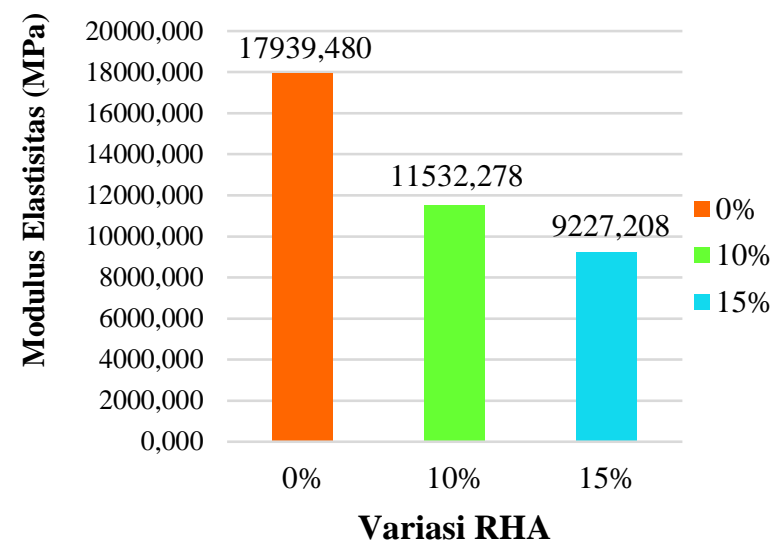

Gambar 19. Hubungan modulus elastisitas beton dan variasi $\mathrm{RHA}$

Berdasarkan gambar 19 di atas menunjukkan hubungan antara modulus elastisitas dengan variasi RHA, yaitu nilai modulus elastisitas beton mengalami penurunan setiap penambahan substitusi variasi RHA pada campuran beton.

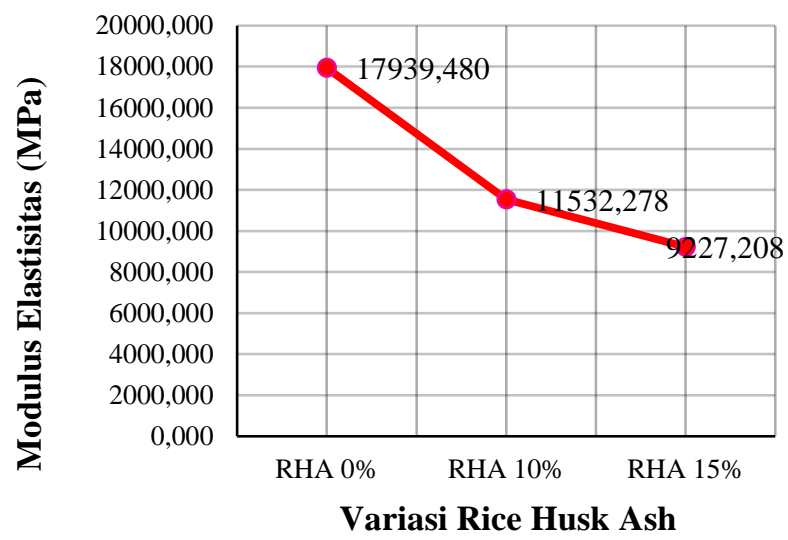

Gambar 20. Hubungan modulus elastisitas terhadap varaiasi $\mathrm{RHA}$
Hasil dari pengujian modulus elastisitas beton dengan kuat rencana (f'c) yaitu $25 \mathrm{MPa}$ pada variasi 'rice husk ash $0 \%, 10 \%, 15 \%$ sebagai substitusi semen dan variasi tetap boittom ash $30 \%$ sebagai substitusi agregat halus pada umur 28 hari yaitu berturut-turut sebesar $17939,480 \mathrm{MPa}, 11532,278$ $\mathrm{MPa}$, dan 9227,208 MPa mengalami penurunan dari variasi $\mathrm{RHA} 0 \%$ ke RHA $10 \%$ menurun sebesar $55,56 \%$, sedangkan variasi RHA 10\% ke RHA $15 \%$ mengalami penurunan sebesar $24,98 \%$.

4. Hubungan antara Kuat Tekan dan Kuat Tarik Beton

Tabel 13. Perbandingan antara kuat tekan dan kuat tarik

\begin{tabular}{cccc}
\hline No & Variasi & Perbandingan (\%) & $\begin{array}{c}\text { Rata-rata } \\
(\%)\end{array}$ \\
\hline 1 & $0 \%$ & 9,383 & \\
2 & $10 \%$ & 8,391 & 8,442 \\
3 & $15 \%$ & 7,553 & \\
\hline
\end{tabular}

Berdasarkan tabel diatas dapat dilihat bahwa perbandingan antara kuat tekan dan kuat tarik belah yang diperoleh pada variasi RHA $0 \%$ sebesar 9,383 $\%$, RHA $10 \%$ sebesar 8,391\%, dan RHA $15 \%$ sebesar $7,553 \%$, sehingga rata-rata yang diperoleh $8,442 \%$ dari nilai kuat tekan beton. Sehingga dari perbandingan tersebut dapat disimpulkan bahwa perbandingan antara kuat tekan beton dengan kuat tarik belah beton telah memenuhi interval yang berkisar antara $7 \%-11 \%$ dengan rata-rata sekitar $10 \%$ dari kuat tekannya.

5. Hubungan antara Kuat Tekan dan Kuat Lentur Beton

Tabel 14. Perbandingan kuat tekan beton dengan kuat lentur balok

\begin{tabular}{|c|c|c|c|}
\hline \multirow[b]{2}{*}{$\begin{array}{c}\text { Kuat } \\
\text { Tekan } \\
\text { Beton }\left(f^{\prime} c\right) \\
{[\mathrm{MPa}]}\end{array}$} & \multirow[b]{2}{*}{$\begin{array}{l}\text { Kuat Lentur } \\
\text { Beton (fr) } \\
\text { [MPa] }\end{array}$} & \multicolumn{2}{|c|}{ Perbandingan } \\
\hline & & $\sqrt{\left(f^{\prime} c\right)}$ & $\frac{f_{r}}{\sqrt{\left(f^{\prime} c\right)}}$ \\
\hline 26,138 & 3,878 & 5,111 & 0,759 \\
\hline 25,572 & 2,921 & 5,056 & 0,578 \\
\hline 25,289 & 2,871 & 5,028 & 0,571 \\
\hline
\end{tabular}

Sehingga dari tabel diatas dapat disimpulkan bahwa pada variasi RHA 0\% nilai kuat lentur beton mencapai $0,759 \sqrt{f^{\prime} c}$ dari nilai kuat tekan beton, RHA $10 \%$ nilai kuat lentur $0,578 \sqrt{f^{\prime} c}$ dari nilai kuat tekan, dan RHA $15 \%$ nilai kuat lentur $0,511 \sqrt{f^{\prime} c}$ dari nilai kuat tekan, sehingga diperoleh nilai rata-rata sesuai dengan SNI 2847:2013 Pasal 9.5.2.3 adalah : $\mathrm{fr}=0,62 \sqrt{f^{\prime} c}$. 
Persentase modulus keruntuhan pada variasi $\mathrm{RHA}$ $0 \%$ yaitu $14,84 \%$ dari kuat tekannya, variasi RHA $10 \%$ yaitu $11,43 \%$ dari kuat tekannya, dan variasi RHA $15 \%$ yaitu $11,36 \%$ dari kuat tekannya. Sehingga nilai yang diperoleh sesuai dengan standar modulus keruntuhan kuat lentur beton yang berkisar antara $11 \%-23 \%$ dari kuat tekannya.

\section{Hubungan Antara Modulus Elastisitas Dengan Kuat Tekan Beton}

Menurut SNI 2847 : 2013, nilai korelasi antara modulus elastisitas beton dengan kuat tekan beton normal dapat dinyatakan dengan persamaan sebagai berikut:

$$
E c=4700 \times \sqrt{f^{\prime} c}
$$

Dari persamaan di atas maka diperoleh modulus elastisitas teoritis pada tiap variasi RHA 0\%, 10\%, dan $15 \%$ berturut-turut sebesar 23976,579 $\mathrm{MPa}$, $23585,137 \mathrm{MPa}$, dan 22637,563 MPa.

\section{KESIMPULAN}

Dari hasil penelitian sifat mekanik beton diperoleh kuat tekan maksimal pada variasi RHA $0 \%$ dan BA $30 \%$ sebesar $26,125 \mathrm{MPa}$, untuk pengujian kuat tarik belah nilai maksimal pada variasi RHA 0\% dan BA $30 \%$ yaitu sebesar $2,451 \mathrm{MPa}$, pengujian kuat lentur pada variasi RHA 0\% dan BA $30 \%$ yaitu $3,878 \mathrm{MPa}$ dan modulus elastisitas maksimal pada variasi RHA $0 \%$ dan BA 30\% sebesar 17939,480 MPa. Pengaruh penggunaan RHA dan bottom ash sebagai bahan substitusi dapat mempengaruhi sifat mekanik beton berdasarkan besarnya variasi, semakin besar variasi yang digunakan kuat tekan, kuat tarik belah, kuat lentur dan modulus elastisitas pada beton semakin menurun. Namun pada penelitian ini kuat tekan beton yang diperoleh pada setiap variasi RHA memenuhi nilai kuat tekan rencana yaitu $25 \mathrm{MPa}$.

Hubungan antara kuat tekan dan kuat tarik belah yang diperoleh pada variasi RHA $0 \%$ sebesar 9,383 $\%$, RHA $10 \%$ sebesar 8,391 \%, dan RHA $15 \%$ sebesar $7,553 \%$, sehingga rata-rata yang diperoleh $8,442 \%$ dari nilai kuat tekan beton.

Hubungan kuat tekan dengan kuat lentur yang diperoleh pada variasi RHA 0\% nilai kuat lentur $0,759 \sqrt{f^{\prime} c}$ dari nilai kuat tekan, RHA $10 \%$ nilai kuat lentur $0,578 \sqrt{f^{\prime} c}$ dari nilai kuat tekan, dan RHA 15\% nilai kuat lentur $0,511 \sqrt{f^{\prime} c}$ dari nilai kuat tekan, sehingga diperoleh nilai rata-rata sesuai dengan SNI 2847:2013 Pasal 9.5.2.3 adalah : $\mathrm{fr}=0,62 \sqrt{f^{\prime} c}$.
Hubungan kuat tekan dan modulus elastisitas yang diperoleh variasi RHA 0\%, 10\%, dan 15\% berturutturut sebesar 23976,579 MPa, 23585,137 MPa, dan 22637,563 MPa.

\section{DAFTAR PUSTAKA}

[1] P. H. L. Tobing, 2018, "Penggunaan Abu Sekam Padi Dan Fly Ash Sebagai PenSubstitusi Semen Pada Beton," J. Online Mhs. JOM Bid. Tek. Sipil, vol. 1, no. 1, Art. no. 1,

[2] S. Pradita, 2012, "Pemanfaatan Abu Dasar (Bottom Ash) Sebagai Bahan Substitusi Pasir Pada Beton Mutu Normal,"

[3] Z. Trisnasari, Wibowo, dan E. Safitri, 2017, "Kajian Pengaruh Variasi Komposisi Rice Husk Ash Terhadap Parameter Beton Memadat Mandiri Dengan Kuat Tekan BetonMutu Tinggi", Matriks Teknik Sipil, vol.5, no.4, doi: https://doi.org/10.20961/mateksi.v5i4.36921

[4] M. Silaturrahmi, 2013, "Pengaruh Pemanfaatan Abu Sekam Padi Pada Campuran Beton Mutu K-250 Kg/Cm²", J. Teknik Sipil dan Arsitektur, vol.1, no.1

[5] Y. Sandya, Prihantono, dan S. Musalamah, 2019, "Penggunaan Abu Sekam Padi Sebagai Pengganti Semen Pada Beton Geopolimer", J. Pendidikan Teknik Bangunan dan Sipil , vol.5, no.2, pp.59-63, doi: https://doi.org/10.24114/ebjptbs.v5i2\%20DES. 16142

[6] SNI 1974 - 2011, "Cara Uji Tekan Beton Dengan Benda Uji Silinder". Jakarta: Badan Standarisasi Nasional

[7] SNI 2491 - 2014, "Metode Pengujian Kuat Tarik Belah Spesimen Beton Silinder". Jakarta: Badan Standardisasi Nasional

[8] SNI 03 - 4431 - 2011, "Cara Uji Kuat Lentur Beton Normal dengan Dua Titik Pembebanan". Jakarta: Badan Standarisasi Nasional

[9] L. J. Murdock and K. M. Brook, 1991, "Bahan Dan Praktek Beton,"

[10] A.S.T.M. C 469 - 02, 2001,"Standard Test Method for Static Modulus of Elasticity and Poisson's Ratio of Concrete in Compression". West Conshohocken: ASTM Internasional. 